\title{
The Effect in Chicks of Feeding a Diet Containing Excess L-methionine on the Ability of the Intestine to Absorb Methionine
}

\author{
Hiro-omi YoKota and Hiroshi Ueda* \\ Laboratory of Animal Nutrition, School of Agriculture, \\ Nagoya University, Nagoya-shi 464
}

(Received July 30, 1980)

\begin{abstract}
The ability of the intestine to absorb L-methionine was measured in chicks fed a diet containing excess L-methionine and then compared with the ability in chicks fed a control diet. Two days after the feeding of $1.5 \% \mathrm{~L}$-methionine-excess diet to $15-$ day old chicks, the cumulative feed intake and body weight gain were significantly less than those of the control chicks. The L-methionine absorptive ability was measured between days 4 to day 6 by an in situ perfusion method at methionine concentrations of 2 , 10 and $50 \mathrm{mM}$ in the perfusate. At the two higher concentrations L-methionine absorptive ability of chicks fed a methionine excess diet was less than that fed a control diet, but not significantly. However, when the concentration of methionine in the perfusate was comparatively lower $(2 \mathrm{mM})$, the ability of the chicks fed the excess diet was significantly smaller than that of the chicks fed the control diet during the first 15 minutes of perfusion. Intestinal (jejunum) weight/unit length was not as affected by the excess methionine in the diet as was body weight gain.
\end{abstract}

Jpn. J. Zootech. Sci., $52(1): 53-57,1981$

Earlier studies showed that the ability of chickens to absorb L-methionine was a little inhibited by an increase of protein in the diet ${ }^{1-3)}$. Chicks fed a methionine-deficient diet were fully able to digest and absorb dietary protein ${ }^{4}$. In contrast amino acid absorptive ability in rats was increased with an increase in the protein content of the diet ${ }^{5.6)}$. Similarly, histidine transport was increased with an increase in dietary excess histidine ${ }^{7}$.

It has been reported that excess dietary methionine adversely affected chick performance and elevated plasma methionine level ${ }^{8-10}$. There is, however, no information available concerning the effect of excess methionine on methionine absorptive ability in chicks.

In the present experiment we investigated the methionine absorptive ability of the small intestine in situ in chicks fed a methionine-excess diet.

\section{Materials and Methods}

Diet: The control diet contained $(\mathrm{g} / \mathrm{kg})$ isolated soybean protein 250 , cornstarch 413.45 , glucose 200 , corn oil 40 , cellulose 30 , mineral mixture 61.74 , vitamin mixture 0.75 , choline chloride 2, L-methionine 5 and glycine 2.5. The mineral mixture contained (g/kg of diet) $\mathrm{CaHPO}_{4} \cdot 2 \mathrm{H}_{2} \mathrm{O} 26.18, \mathrm{CaCO}_{3} 14.8, \mathrm{KH}_{2} \mathrm{PO}_{4} 10.0, \mathrm{KCl} 1.0, \mathrm{NaCl}$

* Present adress: University Farm, Faculty of Agriculture, Kagawa-ken 769-28

Jpn. J. Zootech. Sci., 52 (1): 53-57 
6. $0, \mathrm{MgSO}_{4} 3.0, \mathrm{FeSO}_{4} \cdot 7 \mathrm{H}_{2} \mathrm{O} \quad 0.333, \mathrm{MnSO}_{4} \cdot \mathrm{H}_{2} \mathrm{O} \quad 0.333, \mathrm{KI} 0.0026, \mathrm{CuSO}_{4} \cdot 5 \mathrm{H}_{2} \mathrm{O}$ $0.0167, \mathrm{ZnO} \quad 0.062, \mathrm{CoCl}_{2} 6 \mathrm{H}_{2} \mathrm{O} \quad 0.0017, \mathrm{Na}_{2} \mathrm{MoO}_{4} \cdot 2 \mathrm{H}_{2} \mathrm{O} \quad 0.0083$ and $\mathrm{Na}_{2} \mathrm{SeO}_{3} \quad 0.0001$. The vitamin mixture contained (per $\mathrm{kg}$ of diet) thiamin. $\mathrm{HCl} 100 \mathrm{mg}$, niacin $100 \mathrm{mg}$, riboflavin $16 \mathrm{mg}$, Ca-pantothenate $20 \mathrm{mg}$, cyanocobalamine $0.02 \mathrm{mg}$, pyridoxine $\cdot \mathrm{HCl} 6$ $\mathrm{mg}$, biotin $0.6 \mathrm{mg}$, pteroylmonoglutamic acid $4 \mathrm{mg}$, myo-inositol $100 \mathrm{mg}$, para-aminobenzoic acid $2 \mathrm{mg}$, menaphthone $5 \mathrm{mg}$, ascorbic acid $250 \mathrm{mg}$, retinol acetate $10000 \mathrm{IU}$, cholecalciferol $600 \mathrm{IU}$ and $\alpha$-tocopherol acetate $20 \mathrm{mg}$ and butylhydroxytoluene $125 \mathrm{mg}$ as an anti-oxydant. The methionine-excess diet was formulated by adding $1.5 \% \mathrm{~L}$ methionine to the control diet at the expense of cornstarch. The crude protein content was $21.5 \%$ in the control diet and $22.0 \%$ in the methionine-excess diet.

Chicks: Day-old SCWL male chicks were raised on a commercial chick starter diet (20\% crude protein) for 12 days and then on the control diet for 3 days to adapt them to the semi-purified diet. On day 16, 30 chicks were selected on a weight basis and assigned into 6 groups of 5 chicks each so that the average body weight $(129 \mathrm{~g})$ was the same for each group. Three groups were fed either the control diet or the methionine-excess diet for 6 days. The chicks were housed individually and they were given free access to feed and water. Body weight and feed intake were measured daily.

Absorptive ability: YoKoтA ${ }^{2)}$ had previously reported that methionine absorptive ability in chicks became almost constant at 4 to 6 days after the diet was changed from non-protein to high-protein diet or vice versa. The methionine absorptive ability in the present experiment, therefore, was measured at 4 to 6 days of the experimental period after the chicks began to feed on the excess methionine diet. The chicks were placed on an operating table left side down so that an incision could be made on the right side of the abdomen. The jejunum was withdrawn from the abdominal cavity, and the upper and lower ends of the lower jejunum were cut but the mesenteric blood vessels were kept intact. Both ends of the segment were then connected to glass cannulas. The contents of the intestinal lumen were washed out with Krebs. Ringer phosphate solution. The glass cannulas were attached to a re-circulation apparatus ${ }^{11)}$ which enabled fluid to be perfused through the jejunal segment by means of an air injector. Perfusion was carried on for 30 minutes with Krebs-Ringer phosphate solution containing $\mathrm{L}$-methionine at concentrations of 2,10 or $50 \mathrm{mM}$, and $5 \mathrm{ml}$ samples of the perfusate were taken at 15 minutes intervals. Methionine concentration in the perfusate was measured colorimetrically ${ }^{12}$ ) and the L-methionine absorptive ability was determined by the rate of disappearance of methonine from the perfusate. After the perfusion was finished, the mesentery and fat tissues were removed from the intestinal segment, and the weight and length of the intestinal segment were measured.

\section{Results}

Table 1 shows that body weight gain and cumulative feed intake were signif cantly smaller in the chicks fed the methionine-excess diet than those in the chicks fed the control diet starting from day 2 of the experiment. The findings were in agreement with the data of UEDA et al. ${ }^{13)}$. 
Table 1. Body weight gain and cumulative feed intake by chicks fed control diet or one containing excess methionine

\begin{tabular}{|c|c|c|c|c|c|}
\hline \multirow{2}{*}{$\begin{array}{l}\vdots \\
\because\end{array}$} & \multirow{2}{*}{ Diets } & \multicolumn{4}{|c|}{ Days } \\
\hline & & $2^{1 !}$ & $4^{2)}$ & $5^{2)}$ & $6^{2)}$ \\
\hline \multirow[t]{2}{*}{ Body gain weight (g) } & Control & $18.8 \pm 1.0$ & $4 ! .4 \pm 2.0$ & $51.4 \pm 4.9$ & $61.8 \pm 4.1$ \\
\hline & Methionine-excess & $7.0 \pm 1,1^{*}$ & $23.6 \pm 2.2^{*}$ & $27.6 \pm 4.4^{*}$ & $36.0 \pm 3.3^{*}$ \\
\hline \multirow[t]{2}{*}{ Feed intake (g) } & Control & $35.1 \pm 0.6$ & $72.4 \pm 1.2$ & $89.6 \pm 4.9$ & $113.4 \pm 1.6$ \\
\hline & Methionine-excess & $24.5 \pm 0.7 *$ & $50.6 \pm 0.9 *$ & $65.6 \pm 4.0^{*}$ & $86.2 \pm 2.7 *$ \\
\hline
\end{tabular}

1) Mean \pm standard error of mean of 20 chicks. 2) Mean \pm standard error of mean of 5 chicks. * Significantly different from corresponding control value: $\mathrm{P}<0.05$

The L-methionine absorptive ability calculated on the basis of length and wet weight of the intestinal segments from the chicks fed the control and the methionineexcess diets is shown in Table 2. When calculated in terms of length all the values for chicks given the methionine-excess diet were lower, but the difference was significant only after 15 minutes at the $2 \mathrm{mM}$ concentration. When expressed on the basis of wet weight of intestine both the 15 and 30 minutes samples showed significantly reduced absorptive ability on the methionine-excess diet, but no other significant differences were observed.

Table 2 also shows that the methionine-excess diet caused a small but non-significant reduction in intestinal weight per unit length.

\section{Discussion}

Although the body weight of chicks fed the methionine-excess diet was between $86 \%$ to $90 \%$ of those fed the control diet, the weight of the jejunal segment per unit length was lowered to only $93 \%$ on a wet basis. Thus the effect of the methionineexcess diet was rather less on gut weight than on body weight. In the case of re-

Table 2. Effect of excess methionine in the diet of chicks on jejunal weight and ability to absorb methionine

\begin{tabular}{|c|c|c|c|c|c|c|c|c|c|}
\hline & \multirow{2}{*}{$\begin{array}{l}\text { Intestinal } \\
\text { weight }\end{array}$} & & & \multicolumn{6}{|c|}{ Methionine concentration in perfusate } \\
\hline & & & & \multicolumn{2}{|c|}{$2 \overline{\mathrm{mM}}$} & \multicolumn{2}{|c|}{$10 \mathrm{mM}$} & \multicolumn{2}{|c|}{$50 \mathrm{mM}$} \\
\hline & \multirow{2}{*}{$\begin{array}{l}\mathrm{g} \text { wet weight } \\
/ 10 \mathrm{~cm} \text { of } \\
\text { intestine }\end{array}$} & \multirow{2}{*}{$\begin{array}{l}\text { Time after } \\
\text { perfusion }\end{array}$} & \multirow{2}{*}{ Diets } & \multicolumn{6}{|c|}{ Index of absorptive ability } \\
\hline & & & & A & B & A & B & A & B \\
\hline Control & $\begin{array}{l}1.24 \pm(15)^{2)} \\
0.06^{21)}\end{array}$ & 15 minutes & Control & $11 \pm 2^{11}$ & $9 \pm 1$ & $37 \pm 2$ & $31 \pm 4$ & $120 \pm 39$ & $81 \pm 20$ \\
\hline \multirow[t]{3}{*}{$\begin{array}{l}\text { Methionine- } \\
\text { excess }\end{array}$} & $\begin{array}{l}\text { l. } 15 \pm(15) \\
0.03^{\mathrm{a}}\end{array}$ & & $\begin{array}{l}\text { Methionine- } \\
\text { excess }\end{array}$ & $6 \pm 1 *$ & $5 \pm 1^{*}$ & $32 \pm 3$ & $31 \pm 4$ & $78 \pm 13$ & $64 \pm 12$ \\
\hline & & 30 minutes & Control & $16 \pm 2$ & $14 \pm 1$ & $63 \pm 3$ & $53 \pm 4$ & $219 \pm 26$ & $158 \pm 6$ \\
\hline & & & $\begin{array}{l}\text { Methionine- } \\
\text { excess }\end{array}$ & $12 \pm 1$ & $10 \pm 1^{*}$ & $59 \pm 3$ & $56 \pm 3$ & $176 \pm 10$ & $144 \pm 7$ \\
\hline
\end{tabular}

1) Mean \pm standard error of mean. 2) Number of chicks used. *Significantly different from corresponding control value: $\mathrm{P}<0.05$. Index of absorptive ability. $\mathrm{A}: \mu$ mole $/ 10 \mathrm{~cm}$ of intestine. $\mathrm{B}: \mu \mathrm{mole} / \mathrm{g}$ of wet weight of intestine. 
calculation for intestinal weight in terms of $\mathrm{g} / \mathrm{m}$ of intestine $/ \mathrm{kg}$ of body weight the value for chicks fed methionine-excess diet was a little heavier than that for control chicks, but not significantly. Because of no differences in carcass analysis for protein, fat and water content between chicks fed a control and a methionine-excess diet ${ }^{9}$, their composition of the intestine may be the same between two groups of chicks, and might not influence the ability to absorb L-methionine of 2 groups of chicks.

ҮокотА $^{14)}$ demonstrated that absorptive ability of methionine in the intestine significantly decreased in chickens having higher methionine concentration in the blood plasma than that of perfusate. As plasma methionine concentration in chicks fed a methionine-excess diet was $0.06 \mathrm{mM}^{8}$, it is not seemed that the inhibition of methionine absorption at $2 \mathrm{mM}$ in the perfusate was due to the higher plasma methionine concentration in chicks fed the methionine-excess diet.

L-methionine absorption was generally lower in chicks fed the methionine-excess diet compared to that in chicks fed the control diet, although the difference was only significant at a concentration of $2 \mathrm{mM} \mathrm{L}$-methionine. The effect was manifested 15 minutes after the commencement of the perfusion at the two indices of absorptive ability used here, but 30 minutes after the commencement it was seen only on the wet weight basis. In the case of recalculation in terms of $\mu$ mole $/ \mathrm{g}$ of intestine $/ \mathrm{kg}$ of body weight, absorption rate of methionine in chicks fed the methionine-excess diet (684 1 .

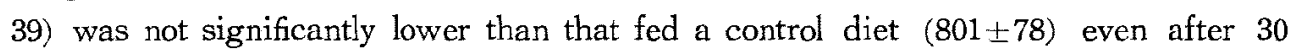
minutes.

Because methionine concentration in the intestinal lumen may be rather high due to the feeding of the methionine-excess diet, the intestine may not adapt to absorb methionine at the lower concentrations. YокотА ${ }^{15}$ ) reported that a carrier for methionine absorption from the intestine begins to function just after the introduction of the amino acid into the intestinal lumen. It is possible that when the concentration in the lumen of chicks fed the methionine-excess diet may inhibit the mobilization of the carrier during the first 15 minutes, but that the inhibitory effect gradually wears off.

As discussed above, methionine absorptive ability was not severely affected by feeding a methionine-excess diet in chicks, although it was a little inhibited particularly at a low concentration of methionine in the perfusate. These results are similar to those of PISANo et al. ${ }^{4}$ who reported that chicks fed a methionine-deficient diet fully absorbed dietary nitrogen in vivo. In rats fed a histidine-excess diet, the transport activity measured using everted sacs was increased several times more than that in rats fed a control diet $^{7}$. It seems likely that there are some differences in the res. ponse of the amino acid absorptive ability to the feeding of amino acid excess or deficient diets between rats and chicks.

The authors wish to thank Dr. Marie E. Coates, National Institute for Research in Dairying for her critical reading the manuscripts. The present work was supported by a grant-in-aid (No. 236029) for scientfic research from the Ministry of Education, Science and Culture in Japan. 


\section{References}

1) Yокота, H. Jpn. J. Zootech. Sc., 47: 233-235. 1976.

2) Yокот, H. Proc. Japan. Soc. Animal Nutr. Met., 21: 13-22. 1977.

3) YoкотA, H. XVI World's Poultry Congress Brazil, 1661-1667. 1978.

4) Pisano, J. J., C. M. Paine and M. W. Taylor, J. Nutr., 67: 213-222. 1959.

5) Goldsmith, R. M., K. A. Munday and M. R. Turner, Proc. Nutr. Soc., 30: 80A. 1971.

6) Lis, M. T., R.F. Crompton and D. H. Matrhews, Br. J. Nutr., 27: 159-167. 1971.

7) Nakamura, Y., K. Yasumoto and H. Mitsuda, J. Nutr., 102: 359-364. 1972.

8) Ueda, H. and I. Tasakr, Japan. Poultry Sci., 14: 138-143. 1977.

9) Ueda, H. and H. Yokota, Japan. Poultry Sci., 14: 236-239. 1977.

10) Ueda, H., H. Yokota and I. Tasaki, XVI World's Poultry Congress, Brazil, 1649-1655. 1978.

11) Tasaki, I. and H. Yokota, Jpn. J. Zootech. Sci., 41: 104-109. 1970.

12) Csonka, R. B. and C. A. Denton, J. Biol. Chem., 163, 329-338. 1946.

13) Ueda, H., H. Yokora and I. Tasaki, Japan. Poultry Sci., 16: 113-120. 1979.

14) Үокота, H. Jpn. J. Zootech. Sci., In preparation.

15) Yoкота, H. Jpn. J. Zootech. Sci., 47: 81-86. 1976.

\section{メチオニン過剩飼料摃取ヒナの腸管における メチオニン吸収能力}

横田浩臣・上田博史

名古屋大学農学部, 名古屋市 464

L 型メチオニンの晹管におけける吸収能力をメチオニン 過剩飼料を撕取したヒナと対照咱料を摄取したヒナとで 測定し比較した。刘照飼料は抽出大豆蛋白質老蛋白質源 とし，メチオニンおよびグリシンを添加した蛋白質含量 $21.5 \%$ 飼料であり，メチオ二ン過剩泀料は対照飼料に 1.5\%のし型メチオ二ンを添加した，過剩飼料を給与一 ると,2日後に增体重および飼料掑取量は対照と比較して 減少したので，メチオニン吸収实験は過剩知料給与関始 後 4 日目加56 日の間化行った. 吸取能力は in situに 打いて再循環型装置を用い, 30 分間に亘り測定し，環流 液からのメチォニンの消失量をるって吸収量とした、環 流液に性 Krebs-Ringer phosphate 溶液を用い, L 型入 チオニンを $2 ， 10$ および $50 \mathrm{mM}$ の浱度に溶解した。 過剩飼料摄取群のとナのメチオ二ン吸収能力は対照飼料
掑取群のものより高くなることはなかった。 $2 \mathrm{mM}$ の場 合には，環流開始 15 分後に书いて過剩帥料提取群の上 ナの吸收量は，対照泀料掑取群のそれに比較して有意に 減少した。この結果より，メチオニン過剩飼料攝取群の ヒナの腸管内には，メチオニンが高浱度に存在し，高浱 度のメチオニンを吸收するようにメチオニン吸收機棈が

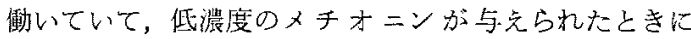
は，それに応答するような吸収㙨棈がすみや加働加 ず，吸收能力を十分発揮できず単位時間の吸取量が減少 したるのと推察される。主た，メチオニン過剩飼料を摈 取すると，単位曼さ当りの腸管重量は減少する傾向に性 あるが，有意差は認められなかった。

日畜会報，52(1)：53-57，1981 